\title{
A CASE OF PRENATAL DIAGNOSIS OF FETAL HYDANTOIN SYNDROME BY ULTRASOUND
}

\author{
Thomaz, Rafael Gollop and Ivan Salzo
}

\begin{abstract}
Fetal hydantoin syndrome (FHS) is a set of disruptions occasionally present in fetuses exposed in utero to phenytoin or other anticonvulsants. Administration of phenytoin in early pregnancy may impair proper psychomotor performance expected for children's development. Several combined phenotypic markers delineate the syndrome, but the presence of single clinical signs is more common. There is controversy about the etiology of FHS. Associated disruptions may be related to a deficiency in a detoxifying enzyme (epoxide hydrolase), vascular problems, and/or factors not yet known. Genetic causes are believed to influence susceptibility to the drug. This text reports an unusual pattern of malformations detected in an ultrasound scan (gastroschisis, sacral meningomyelocele, and absence of the right lower limb) and in the anatomopathological study (left-side gastroschisis, sacral meningomyelocele, scoliosis, left clubfoot, absence of the right lower limb, and pectus carinatum) of a fetus whose mother took phenytoin. These defects may have been provoked by exposure to the drug during embryogenesis. In view of similar malformations observed in cases of prenatal exposure to cocaine, a recognized vasoconstrictor, it is suggested that vascular disruptions of hemodynamic origin constituted the event leading to some of the anomalies caused in the developing embryo. A complication of the chorionic villus sampling procedure, used for cytogenetic analysis, is another possibility.
\end{abstract}

\section{INTRODUCTION}

Phenytoin, the new denomination for diphenylhydantoin, is an efficient hydantoin anticonvulsant. Phenytoin is presumed to disrupt normal development of some fetuses when administered during pregnancy. In the 60's, effects attributed to this medication were grouped into a somewhat recognizable pattern of anomalies (Briggs et al., 1994): fetal hydantoin syndrome (FHS). Classical indicators of FHS were classified by Hanson (1986) into three distinct sets: 1) abnormalities of pre- and post-natal growth - this set includes microcephaly; 2) delay in development, and impaired psycho-motor performance - cases of mental retardation are common, and 3) dysmorphic craniofacial features and limb anomalies. There are many indicators of this last set: short nose, broad depressed bridge, inner epicanthic folds, mild ocular hypertelorism, ptosis of the eyelid, strabismus, wide mouth, sutural ridging, short neck with mild webbing, cleft lip and/or palate, hypoplasia of nails and distal phalanges, increased frequency of low arch digital dermal ridge, and fingerlike thumb. These symptoms vary in each patient. Major anomalies in other systems, as well as cancer, have been reported (Hanson, 1986). Less frequent abnormalities consist of ocular defects, cardiovascular anomalies, hypospadia, and diaphragmatic, umbilical and inguinal hernias (Buehler et al., 1990; Danielson et al., 1992). Each described case displays a unique variation in relation to the pattern originally de-

Instituto de Medicina Fetal e Genética Humana de São Paulo, Rua Félix de Sousa, 321, 04612-080 São Paulo, SP, Brasil. Send correspondence to T.R.G. Fax:+55-11-535-4320.E-mail: trgollop@usp.br / sisalzo@uol.com.br scribed; expression of teratogenic effects in siblings, including dizygotic twins, may be different (Phelan et al., 1982; Strickler et al., 1985; Karpathios et al., 1989). Clinical signs are found in 2.2 to $26.1 \%$ of cases of in utero exposure to phenytoin (Briggs et al., 1994).

Biochemical studies of phenytoin metabolism have been made to identify the mechanisms by which it produces teratogenicity. Reactive arene oxides, produced after phenytoin bioactivation in cytochrome P-450, may bind to DNA and other macromolecules. The rate at which these oxides are converted to harmless compounds by the enzyme epoxide hydrolase may determine the extent of embryonic cell damage (Jerina and Daly, 1974). In earlier stages of embryogenesis, low rates of cell detoxification, a deficiency in the neutralization of the toxic properties of arene oxides by epoxide hydrolase, are thought to lead toward the disruption of normal development. In fact, amniocytes from fetuses who were later diagnosed for the syndrome had low epoxide hydrolase activity (Buehler $e t$ al., 1990). These authors suggested that a single recessive gene might control the enzyme, with low enzyme activity signaling homozygosity for the recessive allele. However, an earlier study of a sample of children affected by FHS and their parents suggested a co-dominant pattern of expression for epoxide hydrolase activity in lymphocytes (Strickler et al., 1985).

A number of studies report vascular disruptions as a possible explanation for some congenital defects observed prenatally, or after birth. In animal models, for example, temporary clamping of uterine vessels is known to affect the development of limbs. In humans, death of a cotwin is an example of these phenomena (Van Allen et al., 1992). Interestingly, Lam et al. (1997) correlate hypoxia and limb anomalies in fetuses afflicted with $\alpha$-thalassemia 
1, who are hypoxic since early gestation. Luijsterburg et al. (1997) illustrate an exogenous reason for vascular disruption: chorionic villus sampling (CVS). These authors reported a case where CVS may have triggered limb and jejunum degradation by apoptotic cell death after an injury to end arteries. There appears to be an inverse association (as pregnancy progresses) between time of CVS and limb reduction defects (Firth, 1997). Several anomalies, like microcephaly (Volpe, 1992), limb reduction anomalies, gastroschisis, neural tube defects (Gingras et al., 1992), and body wall complex (Viscarello et al., 1992), have been detected in fetuses whose mothers used cocaine during pregnancy. All these abnormalities might also be associated with vascular disruption. Recently, Azarbayjani and Danielsson (1998) have raised the hypothesis of a common teratogenic mechanism for antiepileptic drugs, including phenytoin: intermittent hypoxia and dysrhythmia induced by pharmacological properties of some anticonvulsants. In this regard, some anomalies observed in this rare case of FHS could be attributed to vascular disruption. Administration of phenytoin is usually associated with neural tube defects, as it changes the mechanisms of assimilation of folic acid (Briggs et al., 1994).

We report a case of FHS diagnosed after an ultrasound exam at week 19 4/7, and suggest some physiopathological mechanisms acting in disruptions possibly caused by phenytoin use during pregnancy.

\section{CASE REPORT}

A primipara was referred to our institute because of her advanced maternal age (36). She was particularly concerned with the fact of having five mentally retarded first cousins (two males and three females). There were no other cases of mental impairment in her familial history, and she denied consanguinity to her husband. Furthermore, she had been taking $200 \mathrm{mg}$ of phenytoin a day for five years, to control seizures resulting from a car accident. No other drug use was reported. On her first visit, she was warned about possible side effects of the medication, and stopped treatment on week 11 . In addition to cytogenetic analysis, a careful screening by morphological ultrasound was recommended.

The sample of chorionic villi collected on week 10 3/7 revealed a normal 46 XX karyotype. Ultrasound examination, conducted at week $195 / 7$, detected gastroschisis, sacral meningomyelocele, and absence of the right lower limb. Confronted with these findings, the patient elected to terminate pregnancy at week $202 / 7$.

The anatomopathological study of the fetus revealed left-side gastroschisis, sacral meningomyelocele, scoliosis, left clubfoot, absence of the right lower limb (Figure 1), pectus carinatum, normal internal organs, and a weight of $200 \mathrm{~g}$.

\section{DISCUSSION}

Even though this set of anomalies suggests a case of body wall complex, the umbilical cord was visualized in the scan performed on week $195 / 7$. In this occasion, there was a clear distinction between the membranes and protruding internal organs. No changes were detected in amniotic volume, and there was neither adherence of membranes to the body wall, nor amniotic bands.

Some of the anomalies depicted in the case related above are among the most rare effects supposedly caused by phenytoin. In the survey for their article, Oguz et al. (1991) described spinal and sternal anomalies as very sporadic events in FHS cases.

At least two of the defects displayed by the fetus may be associated with vascular compromise. Research has related hypoxia and vascular disruption with a higher incidence of limb and other anomalies. It is precipitous to make any definitive statement; however, some physiologi-

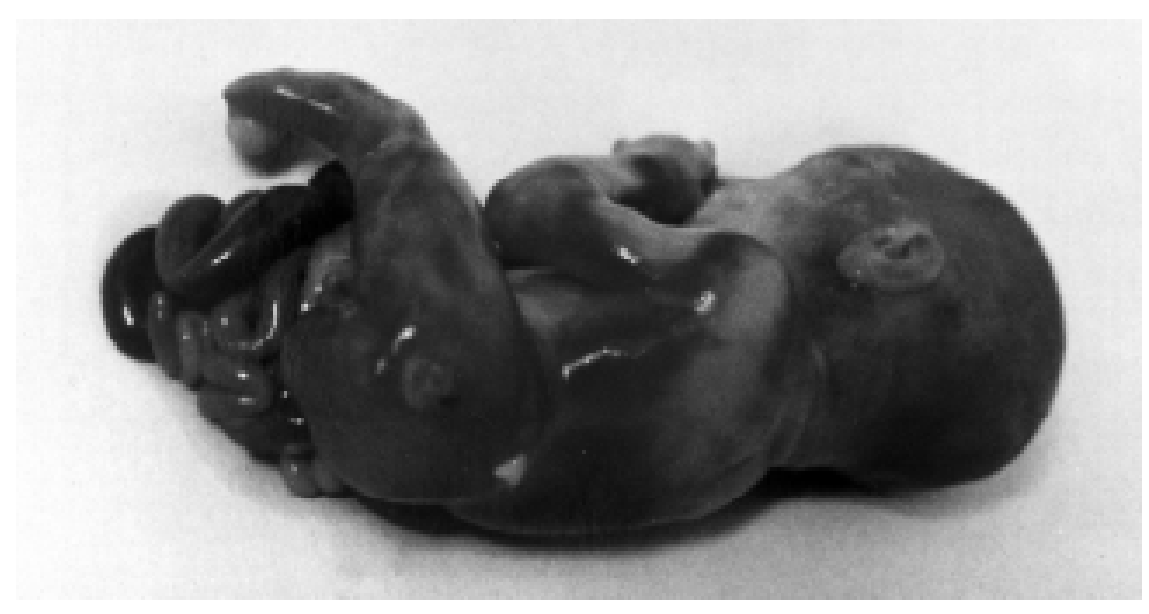

Figure 1 - Gastroschisis, sacral meningomyelocele and left clubfoot in the affected fetus. 
cal properties of phenytoin, cardiodepression and hypotension, for example (Danielson et al., 1992), may more severely affect the placental blood flow in some women and, as a consequence, interfere with normal fetal development, resulting in this rare malformation complex featuring gastroschisis and absence of one limb. Nevertheless, in utero exposure to cocaine could also result in vascular disruption; some evidence of it is gastroschisis and limb anomalies, as stated in the works by Viscarello et al. (1992) and Gingras et al. (1992). Through different means, cocaine and phenytoin may cause vascular disruption and, in this manner, induce some common malformations. Thinking along these lines, an outcome of prenatal exposure to phenytoin could be hypoxia followed by vascular disruption and impairment of developing structures (Danielson et al., 1992). On the other hand, a recent statistical analysis of prenatal exposure to cocaine found no correlation between cocaine use and malformations secondary to vascular disruptions (Hume et al., 1997).

About $50 \%$ of the fetuses exposed in utero to phenytoin will develop early hemorrhagic disease after birth because of low levels of vitamin $\mathrm{K}$ in fetal blood, which suppresses some vitamin K-dependent coagulation factors (Dansky and Finnell, 1991). A deficiency in coagulation factors could also explain some of the disruptions featured in this case. Nevertheless, it is debatable whether or not the injury caused to the villus vascularization would induce absorption of a whole limb and development of gastroschisis. By 10 weeks the body wall should be closed and the limbs, differentiated. Luijsterburg et al. (1997) reported a case of transverse limb reduction defects and jejunal atresia after a transcervical CVS performed on week 9 of amenorrhea. In this respect, the present case displays differences, because there was neither transverse limb reduction, nor jejunal defects; rather there was complete absence of the right lower limb (amely), left clubfoot, and prominent evisceration of organs (gastroschisis). Luijsterburg et al. (1997) correlated their findings with disruptions of end-arteries. Since in the present case there was no right lower limb, and hands showed no signs of disruptions, a different response to vascular damage would have to be considered. Should an injury to an end artery be assumed as the cause for disruptions observed in this report, then apoptotic degeneration of an entire limb must have occurred (as we have mentioned before, there were no amniotic bands and consequently amputation is a remote hypothesis). Additionally, damage to the jejunum somehow would have caused the internal organs to protrude through, and grow outside the body wall. Firth (1997) gathered data on CVS from different sources all over the world, but a pattern of associated disruptions, similar to these in the present case, is not mentioned.

Conversely, there is considerable agreement on the consequences of folate deficiency for the fetus. The case we presented had a neural tube defect, meningomyelocele, that could be explained by a failure in folic acid assimilation through the placenta and also through the mother's stomach and intestines. Again, definitive conclusions cannot be made since there is still disagreement on the role of phenytoin in the dynamics of folate metabolism. Briggs et al. (1994) cite a group of researchers who found no association between neural tube defects and therapy using anticonvulsants.

As far as disruption of fetal development is concerned, questions are always raised on the role of both maternal epilepsy, and the drug used to control it. Phenytoin teratogenicity is probably independent of the maternal disease, insofar as there are reports of FHS cases (Sabry and Farag, 1996) born to non-epileptic mothers.

Because not all of the infants exposed in utero to phenytoin are subjected to its teratogenic effects, there must be genetic factors involved in the determination of the susceptibility to inducing disruptions. In addition to the genes coding for epoxide hydrolase, other genes could also be involved in the route that the drug follows through metabolism. Studies like those performed by Buehler et al. (1990) and Strickler et al. (1985) may be assessing, indirectly, the outcome of other genes that are to a certain extent related to the genes for epoxide hydrolase. A possible physiological outcome of this unknown genetic regulation may be vascular disruption; subsequent defects would be more or less severe, depending on the set of genes present in mother and fetus.

\section{ACKNOWLEDGMENTS}

Publication supported by FAPESP.

\section{RESUMO}

A síndrome da hidantoína fetal consiste em um conjunto de disrupturas por vezes observadas em fetos expostos à fenitoína ou outros anticonvulsivos no período pré-natal. A administração de fenitoína em fase precoce da gravidez pode prejudicar o desempenho psicomotor esperado no desenvolvimento infantil. Diversos indicadores fenotípicos, em conjunto, caracterizam a síndrome, mas a presença de sinais clínicos isolados é mais comum. Há controvérsia quanto à sua etiologia. As disrupturas associadas podem estar relacionadas à deficiência de uma enzima desintoxicante (epóxide-hidrolase), a problemas vasculares e/ou a fatores ainda desconhecidos. Acredita-se haver causas genéticas conferindo susceptibilidade à substância. Este texto relata um padrão distinto de malformações detectadas no período pré-natal ao ultra-som (gastrosquise, meningomielocele sacral, escoliose, ausência do membro inferior direito), bem como posteriormente ao exame anatomopatológico (gastrosquise à esquerda, meningomielocele sacral, escoliose, pé esquerdo torto, ausência do membro inferior direito e pectus carinatum) de feto cuja mãe fez uso de fenitoína. Os defeitos podem ter se originado da exposição à droga durante a embriogênese. Em vista de malformações semelhantes observadas em casos de exposição pré-natal à cocaína, um conhecido vasoconstritor, sugere-se que rupturas vasculares de origem hemodinâmica constituíram o 
evento por trás de algumas das anomalias causadas no embrião em desenvolvimento. Uma complicação do procedimento de coleta de amostra de vilo corial utilizado para análise citogenética é outra possibilidade discutida.

\section{REFERENCES}

Azarbayjani, F. and Danielsson, B.R.G. (1998). Pharmacologically induced embryonic dysrhythmia and episodes of hypoxia followed by reoxygenation: a common teratogenic mechanism for anti-epileptic drugs? Teratology 57: 117-126.

Briggs, G.G., Freeman, R.K. and Yaffe, S.J. (1994). Drugs in Pregnancy and Lactation. 4th edn. Willians \& Wilkins, Baltimore, pp. 378-392 and 692-699.

Buehler, B.A., Delimont, D., van Waes, M. and Finnel, R.H. (1990). Prenatal prediction of risk of the fetal hydantoin syndrome. N. Engl. J. Med. 322: 1567-1572.

Danielson, M.K., Danielsson, B.R.G., Marchner, H., Lundin, M., Rundqvisst, E. and Reiland, S. (1992). Histopathological and hemodinamic studies supporting hypoxia and vascular disruption as explanation to phenytoin teratogenicity. Teratology 46: 485-497.

Dansky, L.V. and Finnell, R.H. (1991). Parental epilepsy, anticonvulsant drugs and reproductive outcome: epidemiologic and experimental findings spanning three decades. 2. Human studies. Reprod. Toxicol. 5: 301-335.

Firth, H. (1997). Chorion villus sampling and limb deficiency - cause or coincidence? Prenatal Diagn. 17: 1313-1330.

Gingras, J.L., Weese-Mayer, D.E., Hume Jr., R.F. and O'Donnell, K.J. (1992). Cocaine and development: Mechanisms of fetal toxicity and neonatal consequences of prenatal cocaine exposure. Early Hum. Dev. 31: $1-24$.

Hanson, J.W. (1986). Teratogen update: Fetal hydantoin effects. Teratology 33: 349-353.

Hume, R.F., Martin, L.S., Bottoms, S.F., Hassan, S.S., Banker-Collins, K., Tomlinson, M., Johnson, M.P. and Evans, M.I. (1997). Vascu- lar disruption birth defects and history of prenatal cocaine exposure: A case control study. Fetal Diagn. Ther. 12: 292-295.

Jerina, D.M. and Daly, J.W. (1974). Arene oxides: A new aspect of drug metabolism. Science 185: 573-582.

Karpathios, T., Zervoudakis, A., Venieris, F., Parchas, S. and Youroukos, S. (1989). Genetics and fetal hydantoin syndrome. Acta Paediatr. Scand. 78: 125-126.

Lam, Y.H., Tang, M.H.Y., Sin, S.Y., Ghosh, A. and Lee, C.P. (1997). Limb reduction defects in fetuses with homozygous $\alpha$-thalassemia 1. Prenatal Diagn. 17: 1143-1146.

Luijsterburg, A.J.M., Van Der Zee, D.C., Gaillard, J.L.J., Losd, F.J., Brandenburg, H., Van Haringen, A. and Vermeij-Keers, Chr. (1997). Chorionic villus sampling and end-artery disruption of the fetus. Prenatal Diagn. 17: 71-76.

Oguz, A., Sezgin, I., Gökalp, A. and Gültekin, A. (1991). The fetal hydantoin syndrome. Mater. Med. Pol. 23: 308-311.

Phelan, M.C., Pellock, J.M. and Nance, W.E. (1982). Discordant expression of fetal hydantoin syndrome in hetero-parental dizygotic twins. N. Engl. J. Med. 307: 99-101.

Sabry, M.A. and Farag, T.I. (1996). Hand anomalies in fetal hydantoin syndrome: From nail/phalangeal hypoplasia to unilateral acheiria (letter). Am. J. Med Gen. 62: 410-412.

Strickler, S.M., Dansky, L.V., Miller, M.A., Seni, M.H., Andermann, E. and Spielberg, S.P. (1985). Genetic predisposition to phenytoin-induced birth defects. Lancet ii (8458): 746-749.

Van Allen, M.I., Siegel-Bartelt, J., Dixon, J., Zuker, R.M., Clarke, H.M. and Toi, A. (1992). Constriction bands and limb reduction defects in two newborns with fetal ultrasound evidence for vascular disruption. Am. J. Med. Gen. 44: 598-604.

Viscarello, R.R., Ferguson, D.D., Nores, J. and Hobbins, J.C. (1992) Limb-body wall complex associated with cocaine abuse: Further evidence of cocaine's teratogenicity. Obstet. Gynecol. 80: 523-526.

Volpe, J.J. (1992). Effect of cocaine use on the fetus. N. Engl. J. Med. 327: 399-407.

(Received April 27, 1998) 